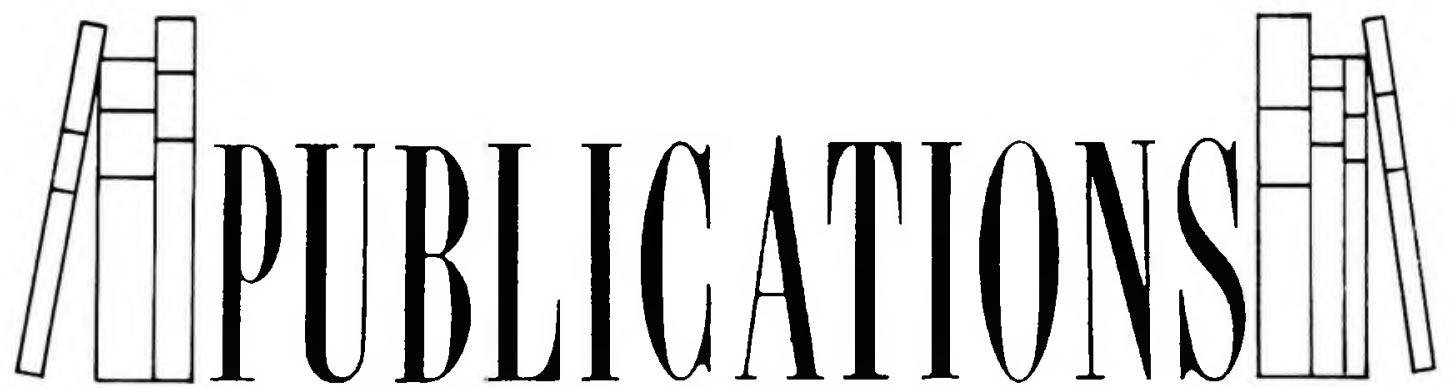

- Access to Library Resources through Technology and Preservation: Proceedings of the 1988 U.S. U.S.S.R Seminar, edited by Robert P. Doyle (155 pages, May 1989), contains the papers presented at a seminar in Washington on July $5-8,1988$, sponsored by the ACLS U.S.-U.S.S.R. Commission on Library Cooperation, administered in the United States by the International Research and Exchanges Board, organized by the American Library Association, and held in cooperation with the Library of Congress. The sessions covered such topics as the automation of libraries and information services in the U.S. and the U.S.S.R., bibliographic control of information in a computer environment, national and international issues in library networking, and the current status of preservation programs. Soviet participants in the seminar included the director of the Lenin State $\mathrm{Li}$ brary, N. S. Kartashov, and the director of the U.S.S.R. State Public Library of Science and Technology, A. S. Sorokin. American participants included Richard DeGennaro, Henriette Avram, Susan Martin, Patricia Battin, Ann Russell, and Peter Sparks. Copies may be obtained for $\$ 25.00$ from ALA Publishing, 50 E. Huron St., Chicago, IL 60611. ISBN 0-8389-7300-0.

- The ACLS Survey of Scholars: The Final Report of Views on Publications, Computers, and Libraries, by Herbert C. Morton, Anne J. Price, and Robert Cameron Mitchell (137 pages, March 1989), contains the results of a 1985 survey of more than 5,000 humanists and social scientists on a wide range of issues related to their experiences as authors and users of scholarly publications, as users of academic libraries, and as users of computer technology in their research and training. The preliminary report originally appeared as a special issue of Scholarly Communication, the quarterly newsletter of the Office of Scholarly Communication and Technology, and was discussed in the February and May 1987 issues of $C \& R L$ News. This final report presents a revised and expanded discussion of the survey findings, as well as 30 additional tables, a new section on the views of retirees, a technical appendix on the survey procedure, and a special analysis of the academic library data by Paul B. Kantor. Copies may be ordered for $\$ 27.50$ (bound) or $\$ 14.75$ (paperback) from University Press of America, 4720-A Boston Way, Lanham, MD 20706. ISBN 0-8191-7260-X; 7261-8.
- Anomalies in Geology: Physical, Chemical, Biological, compiled by William R. Corliss (329 pages, March 1989), is a catalog and bibliography of unusual geological phenomena. Included in this volume (part of a series that now encompasses geophysical, astronomical, and topographical anomalies) are such oddities as living animals entombed in rocks and earth; the causes of biological extinctions and explosions; unusual petrifactions and lignifications; anomalies associated with the origin of oil, coal, methane, and ocean water; unusual surface films on rocks; flexible rock; ringing rocks; zones where natural fission reactors may have existed; luminous and explosive rocks; and unusually radioactive fossils. Each category is rated in terms of anomalousness, briefly described, and supplemented with a representative list of scientific sources. Copies may be ordered for $\$ 18.95$ from The Sourcebook Project, P.O. Box 107, Glen Arm, MD 21057. ISBN 0-915554-23-2.

- Brittle Books Programs, SPEC Kit \#152 (121 pages, March 1989), contains the results of a survey of ARL libraries on the evaluation, bibliographic searching, replacement, preservation photocopying, and preservation microfilming of books and serials that have become too brittle to handle without risking damage. More than $90 \%$ of the 64 libraries that responded have some mechanism in place for systematically identifying brittle books. This kit also contains planning documents, organization charts and job descriptions, selection and searching procedures and forms, guidelines and workflow descriptions, microfilming and photocopying procedures, and a selected reading list. A copy may be ordered for $\$ 20.00$ (prepayment required) from SPEC, Office of Management Services, 1527 New Hampshire Ave., N.W., Washington, DC 20036.

- Checklist of Bibliographies Appearing in the Bulletin of Bibliography, 1897-1987, edited by Naomi Caldwell-Wood and Patrick W. Wood (144 pages, May 1989), is a fully cumulative index to the quarterly Bulletin of Bibliography from its inception in 1897 by the parent company of the F. W. Faxon Company. All articles, reviews, editorials, and bibliographical notes are indexed. The checklist costs $\$ 75.00$ and may be ordered from the Meckler Corporation, 11 Ferry Lane West, Westport, CT 06880. ISBN 0-88736-237-0. 
- Constitutional Issues and Archives, edited by Mary Boccaccio (81 pages, 1988), is a collection of papers presented at the Fall 1987 meeting of the Mid-Atlantic Regional Archives Conference (MARAC), held in Charlestown, West Virginia. This is the first in a series of "Archival Symposia" to be published by MARAC and edited by Erika Thickman Miller. Nine essays address specific topics in freedom of information and personal privacy, privacy issues in documenting society and government, and copyright issues. Copies may be ordered for $\$ 6.00$ from Brother Denis Sennett, MARAC Secretary, Friars of the Atonement, Graymoor, Garrison, NY 10524.

- Directory of Financial Aids for Women, 1989-1990, by Gail Ann Schlachter (464 pages, May 1989), contains more than 2,200 references and cross-references to scholarships, fellowships, loans, grants, awards, and internships designed primarily or exclusively for women. Over $70 \%$ of the continuing programs reported substantive changes in their locations, requirements (particularly application deadlines), or benefits since 1987, the date of the last edition of this directory. The volume is divided into four separate sections: a descriptive list of financial aids, a list of state sources of educational benefits, an annotated bibliography of directories listing general financial aid programs, and a set of five indexes. The book is available for $\$ 42.50$ from Reference Service Press, 1100 Industrial Road, Suite 9, San Carlos, CA 94070. ISBN 0-918276-09-8.

-Enter, Save, Delete...: Libraries Pioneering into the Next Century, edited by Douglas G. Birdsall (1989), contains five papers presented during the Academic Library Section's Research Forum at the joint conference of the Mountain Plains Library Association and the Montana Library Association, April 26-29, 1989. Topics included in this volume are: a proposed method for describing the collection in two-year materials selection policy statements; reference assistant training; the reference librarian, and privacy and accessibility at work; the Billings Area Health Science Information Consortium; and basing journal cancellation decisions on usage data. Copies of this and earlier MPLA proceedings may be requested from Henry R. Stewart, Director of Library Services, William Allen White Library, Emporia State University, Box 51, Emporia, KS 66801.

- Free Magazines for Libraries, by Adeline Mercer Smith and Diane Rovena Jones (228 pages, $3 \mathrm{~d}$ ed., June 1989), includes approximately 500 entries of free "house magazines" in 66 categories of art, business, humanities, social sciences, policy, science, and education. Such titles as Misleading Advertising Bulletin, Political Life in Sweden, Rope Talk, and Tube Topics are described in depth. An introduction discusses the purpose and audience of house magazines and provides hints on where to look for information on other free maga- zines, while an appendix provides a basic list of magazines for small to medium libraries, magazines outstanding for their illustrations, and magazines indexed in periodical indexes and abstracts. The book costs $\$ 19.95$ and is available from McFarland \& Company, Box 611, Jefferson, NC 28640. ISBN 0-89950-389-6.

-Getting Published in Women's Studies: An International, Interdisciplinary Professional Development Guide Mainly for Women, by Helen Rippier Wheeler (241 pages, June 1989), provides guidance for professionals and academics in women's studies who are trying to get published for the first time or who are underpublished. A list of current and accessible resources and a glossary are provided. Copies are available for $\$ 19.95$ from McFarland \& Company, Box 611, Jefferson, NC 28640. ISBN 089950-400-0.

- International Conference on Research Library Cooperation, sponsored by the Research Libraries Group (168 pages, 1988), consists of papers delivered at the conference, which was held at Stanford, October 1-4, 1984. Topics include cooperation in the PICA library network, shared cataloging networks in the Federal Republic of Germany, the linked systems project, new cooperative ventures in the U.K., resource sharing among research libraries, and international cooperation in preservation. Copies may be ordered for $\$ 39.95$ from $\mathrm{Ha}$ worth Press, 10 Alice St., Binghamton, NY 13904-1580. ISBN 0-86656-596-5.

- The Journal of Computing in Higher Education, vol.1, no.l (Spring 1989)- , is a refereed journal to be published by the New England Regional Computing Program (NERComP) semiannually in March and September. Edited by Carol MacKnight, director of the Office of Instructional Technology at the University of Massachusetts, Amherst, the journal will publish scholarly essays, reviews, reports, and research articles that contribute to the understanding of the issues, problems, and research associated with instructional technology and educational management information systems. This first issue includes articles on new tools for courseware production, computerassisted instruction in the liberal arts, and "Technological Innovations in Higher Education: Are They Possible?" Personal subscriptions are $\$ 18.00$ for NERComP members, $\$ 32.00$ for others; library/institutional subscriptions are $\$ 25.00$ for NERComP members, $\$ 42.00$ for others. Order from NERComP, 439 Washington St., Braintree, MA 02184. ISSN 1042-1726.

- Land Husbandry: A Framework for Soil and Water Conservation, by T. X. Shaxson, et al. (64 pages, March 1989), explains how to integrate soil and water conservation measures into agricultural production systems on steep lands throughout the world. The handbook contains applicable guidelines for planning the best use of land resources, new thoughts about the principles of land hus- 


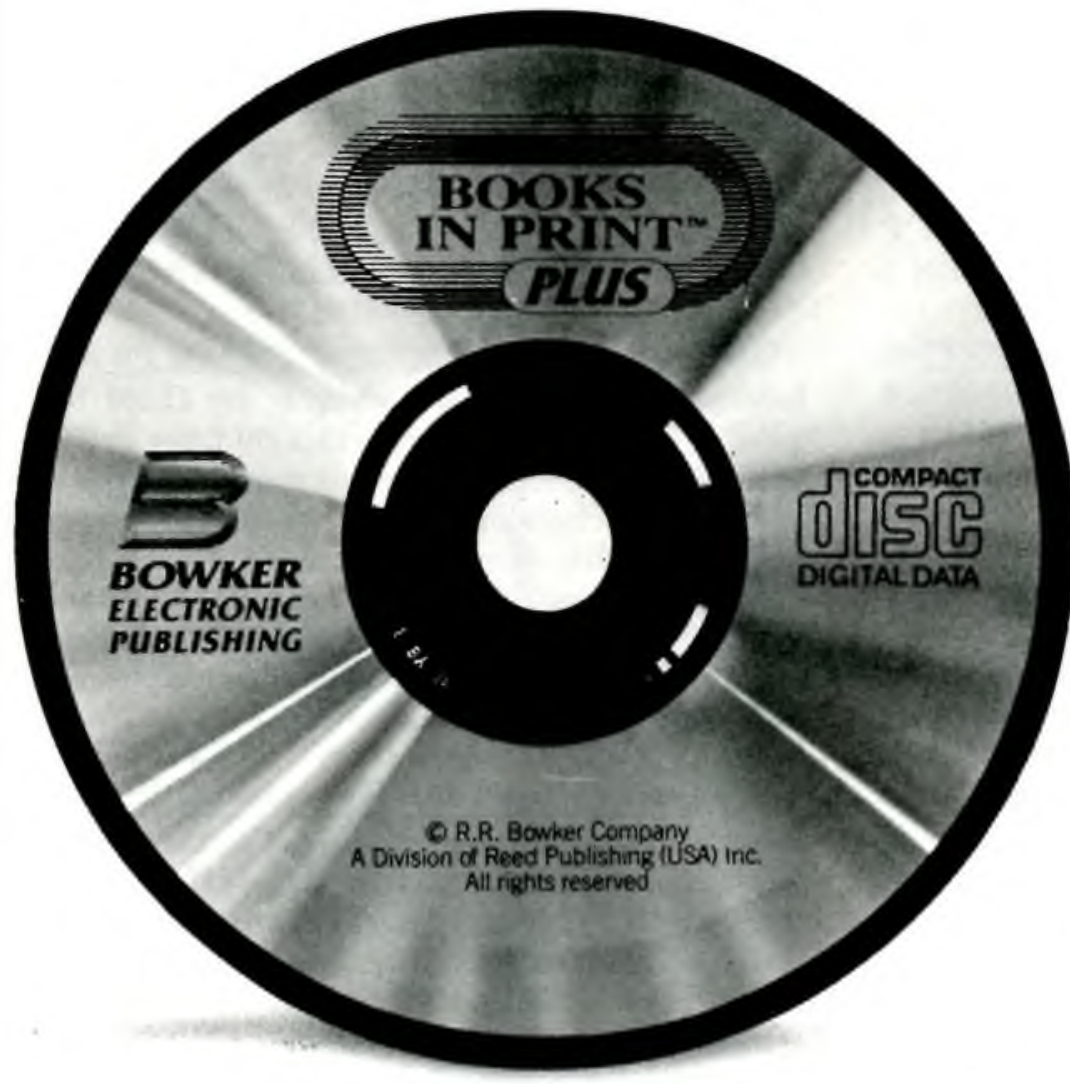

Bowker's BOOKS IN PRINT PLUS"

on $\mathrm{CD}^{-\mathrm{ROM}^{*}}{ }^{*}$ is simply the most powerful

library resource you've ever seen, with more than 770,000 titles stored on the CDROM disc-every title in every volume of the BOOKS IN PRINT FAMILY-

-Books In Print

- Subject Guide to Books In Print

- Supplement to Books In Print

- Forthcoming Books In Print

- Children's Books In Print

And, CD-ROM drastically reduces the time you spend on book reference and acquisitions. What's more-

-It's easy to use-

You'll find that, once your personal computer and CD-ROM drive are in place, four computer function keys will be the basic tools with which you'll work, with on-screen help always a keystroke away.

-It's a time-saver-

Your most complicated searches-even those that use multiple access pointsare available in seconds.

- It's cost effective-

You have unlimited access to Bowker's BOOKS IN PRINT series database without the high expense often associated with going online.

-It's current-

You'll receive fully cumulative updates every three months.

-It's filled with work-saving featuresYou'll be able to edit, print, and save searches-even order books electronically from your favorite distributor.

- Best of all, it's priced right-

A ONE YEAR SUBSCRIPTION TO BOOKS IN PRINT PLUS IS ONLY $\$ 995$.

\section{Special Offer!}

Call our TOLL-FREE HOT LINE to order. Tell the operator where you saw this ad, and you'll get a $\$ 50$ discount off the retail price of $\$ 995$. A $5 \%$ savings just for mentioning this ad.

Call 1-800-323-3288.

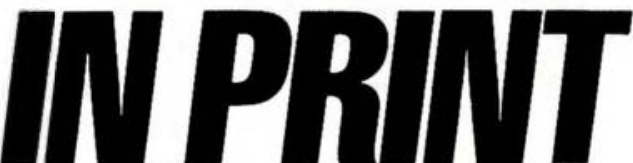

(In NY, AK, HI call collect 212-337-6989.) *CD-ROM (Compact Disc-Read Only Memory) = approx. 250,000 printed pages or 1,500 floppy disks
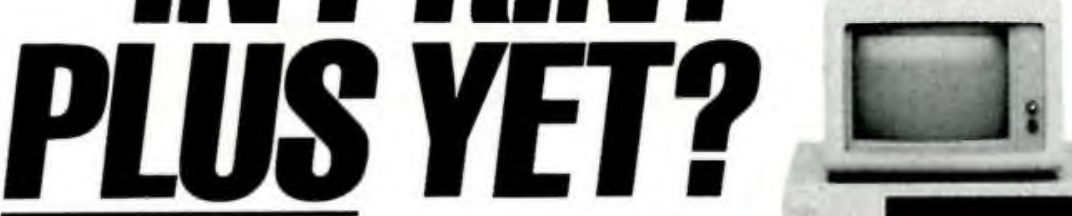

Books In Print PLUS INCREDIBLY

POWERFUL

EASY TO USE RIGHT FOR YOU!
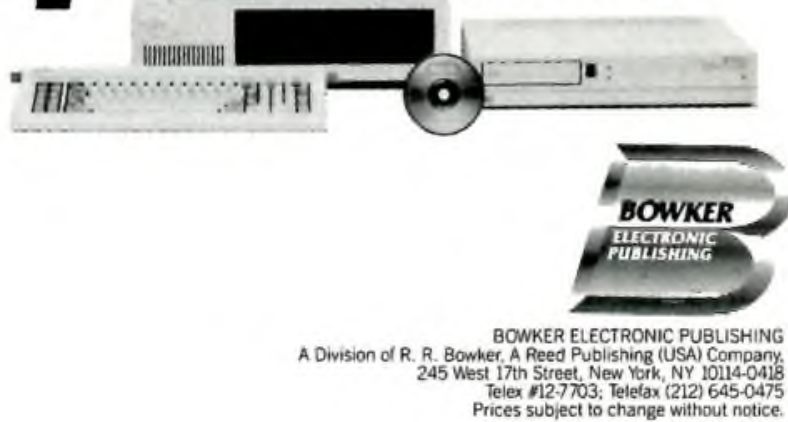
bandry, and a step-by-step guide to practicing conservation principles. It was written by soil and water conservationists following an international conference held in March 1987 in San Juan, Puerto Rico. Copies are available for $\$ 12.00$ from the Soil and Water Conservation Society, 7515 N.E. Ankeny Road, Ankeny, IA 50021-9764. ISBN 0935734-20-1.

- Les Nouvelles Frances: France in America, 1500-1815, an Imperial Perspective, by Philip P. Boucher (122 pages, 1989), is the catalogue of an exhibition at the John Carter Brown Library commemorating the bicentennial of the outbreak of the French Revolution. Illustrated with many maps, engravings, and sample pages, the catalogue relates the history of New France with ample references to the materials in the Brown University exhibition and the impact they had on the politics and culture of early America. Copies may be requested from the John Carter Brown Library, Box 1894, Providence, RI 02912.

- Managing the New Electronic Information Products, by Stephen E. Arnold and Linda Rosen (200 pages, June 1989), is a guide for librarians facing purchase or management decisions on CDROM products. Included are sections on how to develop a strategic plan for CD-ROM; a review and assessment of CD technology; how to find support and funding for acquisitions; and a glimpse into the future of optical technology. Copies may be ordered for $\$ 24.95$ from Riverside Data, P.O. Box 545, Sudbury, MA 01776.

- OPACs and Beyond (120 pages, 1989) has been published as volume 10 in the OCLC Library, Information, and Computer Science series. Papers published in this book were presented at the OCLC Online Computer Library Center in Dublin, Ohio, August 17-18, 1988, during the second in a series of invitational meetings sponsored by the British Library, the Direction des Bibliothèques, des Musées et de l'Information Scientifique et Technique (DBMIST), and OCLC. Many aspects of Online Public Access Catalogs (OPACs) are covered in this volume, including OPAC research in the United Kingdom, subject authority control, communicating in natural language, and union catalogs on personal supercomputers. Copies may be obtained for $\$ 12.50$ (non-OCLC members must prepay) from OCLC, Dept. 630, Box ONB, Columbus, $\mathrm{OH}$ 43265. Specify product code 8086 . ISBN $1-55653$ 070-6.

- The Oxford Companion to Classical Literature, edited by M. C. Howatson (615 pages, 2 d ed., May 1989), is an encyclopedia of literary, politica', s. cial, and artistic achievements of the Classical Age, from the entry of the Greeks into Greece around 2200 B.C. to the 6 th century A.D. There is ample coverage of the development of various literary forms, such as epic, rhetorical writing, comedy and tragedy, and a full explanation of poetic metre. Supplementing extensive biographical entries are articles on the origins of the Greek and Latin alphabets and languages, while entries on books and writing and the transmission of ancient texts tell of the dissemination of these works and their collection in the great libraries of the Hellenic world. The book costs $\$ 39.95$ and is available from Oxford University Press, 200 Madison Ave., New York, NY 10016. ISBN 0-19-866121-5.

- Selecting Library Furniture: A Guide for Librarians, Designers, and Architects, by Carol R. Brown (112 pages, 1989), provides guidance in determining the specific furnishing requirements for a library and choosing furniture of an appropriate type and quality to meet those needs. Ninety-five illustrations show current trends in library furnishings and help describe the technical considerations of furniture selection. Copies may be ordered for $\$ 25.00$ from Oryx Press, 2214 N. Central at Encanto, Phoenix, AZ 85004. ISBN 0-89774-535-3.

- Toward the Year 2001: Cooperative Collection Development and Resource Sharing in the Southwest, edited by Bart Harloe (49 pages, 1989), features papers and proceedings of a workshop on library cooperation held in Las Cruces, New Mexico, in November 1988. Following a keynote address by Paul Mosher, Jeanne Sohn discusses cooperative collection development from a New Mexico point of view, Dora Biblarz covers the topic of collection development policies and the Arizona experience, Sara Heitshu addresses the technical issues involved in resource sharing and cooperative collection development, and Mary Keckley describes trans-border cooperation and the Texas experience. An audiotape and printed version may be obtained for $\$ 14.50$ (printed only, $\$ 8.50$; audiotape only, \$8.50) from Patsy Hernandez, Collection Management Department, New Mexico State University Library, Box 30006, Dept. 3475, Las Cruces, NM 88003-0006. Orders must be prepaid, with checks made out to the NMSU Library.

-The Vampire in Literature: A Critical Bibliog-

raphy, edited by Margaret L. Carter (143 pages, May 1989), covers all aspects of vampire fiction and non-fiction. Entries include anthologies of vampire fiction and verse, non-English vampire fiction in translation, and drama. The bibliography is preceded by three critical essays, "The Study of Vampirism in Literature" and "An Anatomy of Vampirism" by Margaret Carter, and "The Vampire in Legend, Lore and Literature," by Devendra $P$. Varma. Particular attention is paid to variations on vampirism in science fiction and fantasy, touching upon such topics as vampire plants, Lovecraftian entities, and psychic predators. Copies are available for $\$ 34.95$ from UMI Research Press, 300 N. Zeeb Road, Ann Arbor, MI 48106. ISBN 08357-1998-7.

- The Virginia Atlas and Gazetteer (80 pages, 1989 ) is the latest in a series of superb state topographic maps published by the DeLorme Mapping Company. The level of detail is excellent for those 
who like to backpack across rugged terrain or take back roads without getting lost. No folding state map comes close to this for locating place names, recreational areas, campgrounds, canoe trips, bicycle routes, fishing areas, Civil War sites, museums, wildlife areas, scenic drives, and wineries. The series now covers Florida, Pennsylvania,
Ohio, New York, Vermont, New Hampshire, Maine, Michigan, Wisconsin, Washington State, and California. Atlases for Minnesota and Tennessee will be published soon. Each atlas costs $\$ 12.95$ and is available from DeLorme Mapping Co., P.O. Box 298, Freeport, ME 04032.

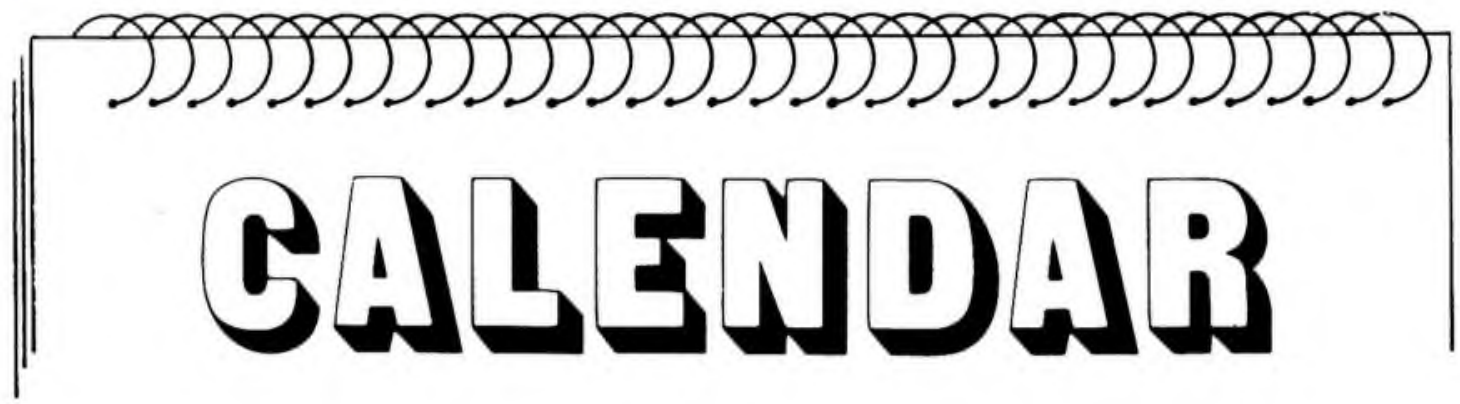

\section{September}

17-19-Management technology: The Midwest Chapter of the Medical Library Association (MC/MLA) will hold their 39th annual conference at the Pfister Hotel in Milwaukee. The conference this year will offer a two-track program with a focus on new and emerging technologies in the control and management of information with a second focus on managerial and economic issues in small medical libraries. Key speakers include Jennifer Cargill, Beverly Lynch, Jane Robbins, Sherrilynne Fuller, and Mary Hutchings Reed. Special events will be a vendor exhibit and a computer lab-free instruction on IBMPC equipment in a fully operational 20 workstation PC lab. Fee: \$95. Contact: Sharon Wochos, Health Sciences Library, St. Mary's Hospital, 2323 N. Lake Drive, Milwaukee, WI 53201.

\section{October}

3-6-Management skills: The Office of Management Services is offering a three and a half day program in Baltimore, Maryland, focusing on the individual's relationship to the library organization and to others within the organization. Designed with library professionals with managerial, administrative, or supervisory responsibilities in mind, the program covers the areas of group leadership, interpersonal skills, and organizational diagnosis. Fee: $\$ 375$. Contact the OMS Office Manager at 1527 New Hampshire Avenue, N.W., Washington,D.C. 20036; (202) 232-8656.

10-13-Information management: "Teamwork and Technology" will be the theme for INFO 89, the Information Management Exposition and Conference at the Javits Convention Center, New York. The topics for the first three keynote speakers will be "Aligning Information Systems and Corporate Goals," "Using Technology to Enhance Your Business Success," and "Develop- ing an Information Infrastructure." INFO covers the entire range of information products for business and concentrates on PC integration and multi-vendor environments. Exhibits include PC's, PC-to-mainframe integration systems, minicomputers, connectivity products, local area networks, peripherals, telecommunication and datacommunication systems, desktop publishing and presentation systems, computer security, data storage systems, high-speed output devices, facsimile systems, and the largest collection of business-oriented software at any U.S. event. Contact: Show Manager, INFO 89, 999 Summer St., Stamford, CT 06905; (203) 964-0000.

12-13 - Databases: The University of Toronto announces the second conference on database users, to be held in Toronto. The goal of the conference is to bring together people in the industrial and academic communities who are concerned with the behavior of database users. Prominent speakers from across North America will present the latest research findings and industrial experience in the areas of user demographics, methods of studying user behavior, user training and assistance techniques, and recent changes in database content and technology. The program will be of interest to all types of information professionals concerned with developing and using database systems. Sponsors are the University's Faculty of Library and Information Science (FLIS) and the Canadian Association of Data and Professional Services Organization/Association canadienne des entreprises de services en informatique (CADAPSO). The registration fee is $\$ 195$ Canadian or $\$ 160$ U.S. Student registrations are $\$ 35$ Canadian or $\$ 28$ U.S. Contact: Charles Meadow, Faculty of Library and Information Science, University of Toronto, $140 \mathrm{St}$. George Street, Toronto, Ontario M5S 1Al; (416) 978-4665. 